\begin{tabular}{|lr|}
\hline $\begin{array}{l}\text { Social Work/Maatskaplike Werk Vol } \\
\text { http://socialwork.journals.ac.za/pub }\end{array}$ & No Issue 1 \\
\hline
\end{tabular}

RHETORIC VERSUS REALITY IN SOCIAL WORK PRACTICE: POLITICAL, NEOLIBERAL AND NEW MANAGERIAL INFLUENCES

Thembeni True-love Dlamini, Vishanthie Sewpaul SEWPAUL@ukzn.ac.za

This article is based on a study of the experiences of social workers employed in a public service organisation in the Ethekwini Municipality in KwaZulu-Natal, South Africa. The Constitution of the Republic of South Africa and the profession of social work commit to the pursuit of human rights, social justice and a better life for all. However, an increasing shift towards neoliberalism and new managerialism impacts on the functions and levels of satisfaction of social workers as they deal with the ideal aspirations of the profession and the realities of their day-to-day practice. Informed by critical theory, the research was inspired by the desire for social workers to use the research process to engage in ethical political resistance. 


\section{RHETORIC VERSUS REALITY IN SOCIAL WORK PRACTICE: POLITICAL, NEOLIBERAL AND NEW MANAGERIAL INFLUENCES}

\section{Thembeni True-love Dlamini, Vishanthie Sewpaul}

\section{INTRODUCTION}

The research on which this article is based was designed to understand the experiences of social workers in one public service organisation, the Department of Social Development (DSD), in the Ethekwini region in South Africa. It focused on how social workers explained the discrepancies between their preferred roles and responsibilities and the realities of their day-to-day practice. Informed by critical theory, the research was inspired by the desire to awaken social workers' consciousness to the structural injustices that exist in their work environment, and for them to engage in ethical political resistance. Critical theory recognises the political dimensions of research and supports the importance of research being used to engender change (Humphries, 2008; Miller \& Brewer, 2003). Sewpaul (2014b, 2014c) highlights the relationship between social work education and research, underscored by critical theory, and democratic practices and social change. One of the chief contributions of critical theory to qualitative research is the awareness of "the political-ideological character of research" (Alvesson \& Sköldberg, 2009:11), and the importance of "breaking down the institutional structures and arrangements that reproduce oppressive ideologies" (Rensburg, cited in Henning, 2004:23).

Critical theory is based on the premise that oppressive social structures are reproduced through political and economic power, and the legitimising state apparatus (Dominelli, 2002; Humphries, 2008; Sewpaul, 2015). The relevance of this theoretical framework to this study is that we assumed that social workers are oppressed on account of new managerialist and neoliberal practices, as documented in the literature (Dominelli, 1996; Ferguson \& Lavalette, 2006; Hölscher \& Sewpaul, 2006; Lavalette \& Fergusson, 2007; Sewpaul \& Hölscher, 2004; Sewpaul, 2013) and through our experiences in the field. We believed that it is possible, although difficult, to challenge political forces and organisational functioning and decisions through a collective voice and action. The idea was to develop a counter-hegemonic consciousness against neoliberal and new managerialist discourses and practices, for as Fuchs and Sandoval (2008:113) assert, "Critical theory ... deconstructs ideologies that claim that something cannot be changed and shows potential counter tendencies and alternative modes of development and thinking". The theory accepts that change does not come automatically, and that practical strategies have to be adopted to engineer change within systems. Critical theory negates capitalism by embracing the notion of free-thinking individuals who are more than mere economic subjects, and by the interpretation of freedom as something that humans have to actively struggle for (Fuchs \& Sandoval, 2008). On that note, we wanted to engage social workers in reflexive dialogue, with the hope that by challenging taken-for-granted assumptions and oppressive structures (Freire, 1970, 1973; Gramsci, 1988; Sewpaul, 2014b), social workers might take constructive action to challenge the system and adopt their preferred roles and responsibilities. 


\section{METHODOLOGY}

The main aim of the study was to understand how social workers explained the discrepancies between the profession's commitment to social justice, human rights and engendering structural changes and the day-to-day lived realities of their work.

The key objectives were to understand:

- The major roles and responsibilities of social workers in the organisation;

- Social workers' level of satisfaction with their current functioning;

- Social workers' day-to-day activities in relation to their preferred ideals in relation to social justice, human rights and anti-oppressive practice;

- What factors might prevent social workers from engaging in their preferred roles and responsibilities;

- Social workers' responses to the development of heightened awareness of structural injustices in the workplace.

A qualitative paradigm was adopted in this study. This paradigm involves naturalistic approaches to the world, studies people in their settings, and emphasises the meanings that people attach to their experiences (Denzin \& Lincoln, 2011; Rubin \& Babbie, 2011). This approach allowed us to conduct an open and flexible investigation that adopted inductive reasoning (Terreblanche \& Durrheim, 1999), and to present thick descriptions of data (Neuman, 2006). Qualitative research is suited to investigating complex and sensitive issues, understanding the lived experiences of people by interacting with them in their environment (Denzin \& Lincoln, 2011), and to acquiring details and insights into feelings and thought processes, and personal opinions (Rubin \& Babbie, 2011).

A multi-phase research process was used to meet the objectives of the study. Data were collected through 10 individual in-depth interviews and one focus group session with 21 participants. All data collection occurred on site at the agency, which allowed for first-hand observation of the working environment. In phase one in-depth interviews, which were taperecorded and transcribed verbatim, were conducted. In phase two a focus group session was used: (1) to discuss the findings of the study with the social workers in order to increase the trustworthiness of the data; (2) implement a Freirian strategy of praxis to raise consciousness about the impact of current working conditions on the practices of social workers; and (3) to discuss possible ways forward with social workers in dealing with the profession's core mandates towards social justice and structural changes. The data were analysed through content thematic analysis. All necessary steps to ensure the trustworthiness of the study in respect of credibility, conformability, dependability and transferability were adhered to (Lincoln \& Guba, 1985; Shenton, 2003).

All ethical considerations in respect of obtaining informed consent, ensuring anonymity in the reporting of the data and confidentiality, doing no harm and informing participants that withdrawal at any point will produce no negative consequences were adhered to (De Vos, Strydom, Fouché \& Delport, 2010). Only those social workers who volunteered and gave written permission were included in the study. Participants were made aware of the limits to confidentiality in respect of the focus groups. An invitation to participate in the focus group 
was posted on the agency's notice board. Twenty-one of the agency's $37(57 \%)$ social workers chose to participate in the focus group.

\section{KEY FINDINGS}

The main findings of the study are discussed in relation to the following themes: lack of resources and poor working conditions; coping with high caseloads and managing competing demands; bureaucratic control, hierarchal supervision and lack of professional autonomy; political interference in practice; and the erosion of the legitimacy of the profession.

\section{LACK OF RESOURCES AND POOR WORKING CONDITIONS}

All participants in this study expressed frustration about the lack of resources. Some of the social workers worked in deplorable offices. Four offices leaked when it rained, had no windows, the carpets were dirty and had rain maps on them. Social workers were sitting on torn chairs, ceiling boards were falling and electrical wiring was hanging out, posing a threat to their safety. The toilets did not have cleaning material and had a foul smell. It was not surprising that, under such circumstances, social workers expressed their sense of a total lack of validation. In addition, they expressed the view that their working conditions impacted on their ability to validate their service users. Some participants stated that the appalling conditions of their offices did not instil feelings of hope in service users.

Of the 37 social workers in the agency, only 15 had computers. There were three small printers and two central printers, which caused much delay, as there were often queues for printing and photocopying. There were only seven cars shared among 37 social workers, who were hounded about targets that needed to be met in the face of diminishing resources, contributing to demoralisation and demotivation. One participant stated, "My heart never rests because I know that the outputs are needed, but there are no resources to fulfil this demand".

The shortage of resources created division, tension, fighting and an unacceptable atmosphere among the social workers. Some indicated that they sometimes reverted to "stealing" cars on the days when they had no car allocated to them because of the pressure from management to meet targets. The lack of resources made it very difficult for them to respond to emergency situations. Detailing the impact of neoliberalism and new managerialism, Hölscher and Sewpaul (2006:174) stated that "social workers in post-apartheid South Africa battle with diminishing resources in relation to increasing numbers of service users, spreading our professional time and resources of financial and material aid increasingly thinly". Social workers across the spectrum in South Africa migrate internationally in pursuit of better salaries and working conditions, as these are dismal in urban and rural areas (Alpaslan \& Schenck, 2012; Hölscher \& Sewpaul, 2006; September, 2007). This is despite the fact that the White Paper for Social Welfare (Department of Welfare, 1997) identified the poor salaries, and the service and working conditions of personnel in the welfare sector as major concerns and proposed that these be addressed as a matter of urgency. However, 18 years later these remain major concerns. Apart from expressions of intense dissatisfaction with the poor salaries, resources and working conditions, social workers also had to deal with high caseloads and competing demands. 


\section{COPING WITH HIGH WORKLOADS AND MANAGING COMPETING DEMANDS}

All social workers reported that they had to deal with high workloads, which they were unable to manage, and that they were unable to meet targets. One of the participants stated that:

"There is just too much on our plate ... I do foster care placements, monitoring and supervision of those placements. I issue social relief of distress, I do guardianship reports, I'm part of an elderly program, I do late registration of birth requests for clients who do not have Identity books or birth certificates ... I do family preservation in family conflicts, I do removals of children who are in abusive circumstances or homes. I do counselling for bereaved and troubled individuals. I do awareness campaigns at schools and at communities regarding different issues. I attend war room meetings, I do administrative work whereby I open and sort my files, write minutes and agendas, attend court inquiries, write and submit monthly reports, compile and consolidate statistics of non-financial data of the office, it's just a lot. I can 't finish them all."

The average caseload of social workers in the agency was 1:150 per year, a high number considering the complexity of cases, the fact that social workers do much more than casework, and that they have to manage these tasks with very limited basic resources. In its Framework for Social Welfare Services document, the DSD (2013) recommends with $80 \%$ of a social worker's workload allocated to casework, involving travelling and court work - a caseload of 1:19 cases per month or 1:134 cases annually. In some instances caseloads, particularly in the face of the impact of HIV/AIDS, reach as high as 450 per social worker (Baldauf, 2010), with the NGO sector being particularly overburdened (September, 2007).

In 2004 the National DSD declared social work a scarce skill in South Africa. In response to the shortage of social workers, which is a major contributing factor to the high caseloads of social workers, the DSD developed a Recruitment and Retention Strategy, which was officially launched in March 2009 by Minister Bathibile Dlamini. In a foreword to the Strategy ${ }^{1}$ Minister Zola Skweyiya indicated that:

"The services of Social Workers are considered crucial towards helping the social development sector to deal effectively with various social problems ranging from services to vulnerable groups, substance abuse, HIV and AIDS, chronic poverty, food insecurity and other related social conditions. The provision of the afore-mentioned services is informed by the constitutional, legal and international obligations as well as policies and programmes that are central to the mandate of the department in contributing towards the creation of a developmental state."

The proposals contained in the Recruitment and Retention Strategy, which focused on stemming the loss of social workers through movement to other sectors and through

${ }^{1}$ http://www.nawongo.co.za/UserFiles/Recruit\% 20and\%20Retent\%20Booklet.pdf 
emigration, improving salaries and service conditions for social workers, and the provision of scholarships to recruit students into the profession, received attention in the Cabinet and the National Treasury. The DSD made available R69 million in the 2007/2008 financial year and R117 million in the 2008/2009 financial year for social work scholarships, and actively recruited high school learners into the social work profession. This contributed to a dramatic increase in the number of social work applications across the country and in the intake of social work students. While the DSD declared social work a scarce skill, the Ministry of Education did not endorse this. The Department of Labour, however, on the basis of data provided by the Sector Education and Training Authorities' (SETAs) research and consultations with stakeholders, in an information brochure lists social work as a scarce skill. ${ }^{2}$ But social work does not appear in the National Scarce Skills list: Top 100 Occupations in Demand list (Department of Education and Training, 2014). The National Scarce Skills list drew, in part, from the National Development Plan (NDP 2010-2030), which specifically addresses the skills deficit in the welfare sector, including social work.

It is thus unfortunate that social work is not reflected in the National Scarce Skills list, and did not translate into social work receiving a higher ranking in the Classification of Educational Subject Matter (CESM) document, which would have made a difference to the subsidy received for social work education and training. Furthermore, despite being declared a scarce skill, employment opportunities for social work graduates remain dismal. The current estimate is that about 1500 graduates, the majority of whom are DSD scholarship beneficiaries, have not been employed since 2012. Vacancies in the public sector are not filled on account of lack of finance and office space, and the low numbers of personnel to provide the requisite supervision for those entering the workforce. The lack of a coherent and carefully planned human resource strategy in the DSD remains a huge challenge.

Social workers in this study saw a misfit between what they were doing and what their professional mandates were, as reflected in the voice of the following participant:

"We should be encouraging radicalism, we should be bulldozers when it comes to social justice, but there is just so much that is happening in this office that we even fail to go out there and say to people we stand for social justice... We rarely have time to even go out and teach, train and raise awareness of the structural injustices happening in their lives and prepare them to take necessary action. Human rights is another document that is beautifully written but its implementation is not possible...it's just not practical."

\section{BUREAUCRATIC CONTROL, HIERARCHICAL SUPERVISION AND LACK OF PROFESSIONAL AUTONOMY}

It is ironic that the major thrust of new managerialism is professional control, as professionalism requires autonomy where professional use their expertise, knowledge, skills, values and experience acquired thorough professional training, without undue prescriptions.

2 http://www.labour.gov.za/DOL/downloads/documents/useful-documents/skills-developmentact/Scarce\%20skills\%20pam phlet_pamphlet.pdf 
Howe (1996) states that, as a result of managerialist control, social work now involves a shift from depth to surface work, while Dominelli (1996) writes of the de-professionalising of social work. In the designated organisation, which was the focus of this study, if a social worker needed to go out of the office, be it for a home visit, to respond to emergencies, attend meetings outside the office or attend court proceedings, he/she needed three people to authorise the trip before a car could be used. Permission had to be obtained from a manager, a supervisor and an administrative staff member. Programme coordinators struggled to fund awareness and training programmes because all funding was requested from a centralised head office, and the processes that the requisition had to go through for approval before it reached head office were cumbersome and filled with red tape. Delays were plentiful and all too often requests were lost.

All participants stated that they felt oppressed by management, who did not take their ideas and opinions seriously, and that they were "silenced" on account of the severity of management's oppressive stance. Social workers had come to "abide by the rules" and "not question" management on critical issues. To be more precise, they expressed the view that it was forbidden to even mention injustice in the DSD offices. In the poignant words of one participant:

"As much as social workers may want to do justice to their clients ... it is not possible because they don't have such powers. I sometimes feel like an ant in this department. Social workers also almost have the same problems that are faced by their clients; justice is not done to them. Even their human rights are violated. To say it clearly ... social workers are as oppressed as their clients are by those above them."

Young (2004) writes of how powerlessness contributes to diminished capacities and lack of participation in decision-making, and how the powerless are subject to humiliation and disrespect. Such powerlessness has a marked impact on the self-conceptualisation of social workers, highlighted in the metaphor of feeling "like an ant" to describe being reduced to insignificance. The core of the profession's identity is being eroded by neoliberalism and managerialism, which are primarily concerned with governmentality and economic interest (Sewpaul \& Hölscher, 2004), a trend impacting not only on social work practice but education as well (Sewpaul, 2014a).

Because of the protocols that had to be followed, even in requesting social relief for destitute service users, social workers were deterred from advocating for vulnerable people. Reflecting a typical neoliberal mentality, management often accused social workers of draining the Department financially. Sewpaul (2013:22) argued that the emphasis on "getting the job done at the lowest cost in the shortest space of time and with checks and balances, impact on relationship building, the requisite empathic tuning into the life worlds of people ... and the use of emancipatory people-driven processes towards social change and development".

The research interviews and the group discussion showed that the quality of services was dented by new managerial practices, with the focus on databases that were requested from social workers, and filling in forms on a daily basis, which have robbed them of 
time to do real social work and to have an impact on lives. The many reporting forms that had to be filled in, such as the daily diary, process notes, Form 11, Form 1 A, monitoring tools, monthly reports and non-financial data, were seen to be unreasonable and time consuming. All these were filled in for the purpose of quantifying the services of every worker. There was no talk of, or attempt to, gauge the quality of services.

Increased bureaucratisation and standardisation of procedures contribute to the curtailment of the discretionary powers and autonomy of front-line workers (Clarke, 2007; Dominelli, 1996; Hölscher \& Sewpaul, 2006), often culminating in the culture of silence (Freire, 1970; Young, 2004). All participants in this study in both the individual interviews and the focus group complained about management's control over every aspect of their practice. In the words of one participant: "the bureaucracy in this department just demotivates you from wanting to advocate for people. It just makes you keep quiet; we do all the wrong things not because we want to but because we can't argue or question the superior's decisions".

What is interesting in the above is the awareness that "we do all the wrong things" as resistance to an oppressive, silencing environment, perhaps setting in motion an iterative relationship of further repressive responses from management. Stringent rules do not contribute to an ethical workforce (Bauman, 1993). Indeed, the more stringent the rules and the more they violate human dignity, the greater the likelihood of staff resistance that might manifest in a range of unacceptable behaviours. In some instances social workers began to take on the dominant ethos of the department, reflecting a lack of work ethic and abuse of resources - e.g. personal use of the Department's cars and/or not following up on home visits. This creates a circular, tension-filled environment. Such conduct on the part of social workers makes management believe that their strict and coercive approaches are vindicated, but this might in turn contribute to even greater obstructive and unethical practices.

Aligned with oppressive managerial practices was the vertical, hierarchical and controlling nature of supervisory practices. According to Carpenter and Webb (2012), supervision must be geared towards increasing job satisfaction, reducing work stress and burnout, providing assistance with tasks and social and emotional support, and retention of workers within organisations, based on positive relationships between workers and supervisors. This is especially so when the nature of the work requires high levels of personal investment and is complex and emotionally demanding, as it is in the case of social work. In contrast, however, participants in this study asserted that supervision was hierarchal, not well understood by supervisors, and that they had no advocates to protect them from the Department's higher management "dictatorship". To make matters worse, social workers were told to "compromise" and to find ways to "make things happen". Although social work's specific mission is to uphold social justice, it is unfortunate that social workers are themselves subject to injustices in the workplace.

\section{POLITICAL AND GOVERNMENT INTERFERENCE IN PRACTICE}

Although the social workers who participated in this study indicated that they entered the profession with the noble aspiration of wanting to make a difference, political and government interference frustrated their attempts. As practitioners in the public sector, 
they become caught up in political quagmires. They are often required to drop everything and do the bidding of politicians, particularly during election campaigns. By virtue of being employed in the public sector, they are not expected to resist but to demonstrate loyalty. These challenges impact on the quality, quantity and range of social work services. The politicians use social workers for electioneering, where the Minister would, for example, instruct social workers to profile certain households with the promise of providing food parcels and school uniforms. These promises are often not kept after the elections are over. But this impacts on the credibility of social workers, who work at the coalface with communities, and who are accountable to communities. Also, ward councillors bring lists of people residing in their wards in order to secure undue benefits for them in exchange for votes, and there is political pressure on social workers to make recommendations that favour certain people loyal to the ruling party.

One participant expressed the view that: "People who are leading us are politicians, and the problem with that is that they use propaganda to win people's votes. They make too many promises to poor people and they don't deliver on their promises... People are still oppressed, poor and are affected by unemployment, although we have exited apartheid". Fear of politicians and upper management was palpable, as reflected in the voice of one participant: "The problem is that I think we lack a backbone and we are forced to fear management, we fear when we hear the name MEC (Member of Executive Committee in Government) and we feel like urinating on ourselves and we are threatened by the management in regional office".

Given the huge levels of political interference in the roles of social workers in the public sector, and the fact that social workers were often required to do the bidding of politicians, who have a vested interest in people not recognising the structural sources of their life circumstances, it is not surprising that social workers are kept busy with routine activities, with no time for reflexive practice or engaging communities in reflexive dialogue and/or resistance politics. The latter would bring the failures of the current system into question, which is something that, from a political perspective, must be avoided at all costs. This trend is not restricted to South Africa only. Lavalette and Ferguson (2007) discuss the anger and of demoralisation of social workers in local authorities in the UK, while Ioakimidis (2013) provides substantial details of political intervention in social work on a global level. He describes the collective action of social workers in Greece, and the opposition of the trade union of local authority workers to the government's instructions for social workers to implement unfair legislation (Ioakimidis, 2013).

\section{THE EROSION OF THE LEGITIMACY OF THE PROFESSION}

Social workers were of the view that political interference eroded the legitimacy of the profession. Nine out of the ten participants in the in-depth interviews reported that they thought that the DSD was the reason that social work was not recognised as a legitimate profession. If social workers resisted the behest of the politicians and upper management, they were "shouted at like children", threatened with losing their jobs, and victimised by management. Two of the participants reported that they had been targeted 
"to be dealt with" because they verbalised their concerns. All participants reported that they were dissatisfied about the deployment of MECs, and non-social work staff in the Department. Five asked why deploy a nurse as an MEC instead of a social worker, who understands the processes and challenges of the profession. The latter point was also raised at the Social Work Indaba at the ICC, Durban, 25-27 March 2015. Participants were of the view that the deployment of non-social workers in key social work positions undermined social work as a profession, as the impression created was that the profession could not produce leaders. One participant asserted that:

"I think there is a lot that needs to be done before social work can be realised and felt by the people. I'm saying this because there are people out there who are saying DSD is degrading this profession of social work and I'm afraid it's true and this will take time to be corrected because it all went wrong up there in the higher levels of the Department, especially at the national level ... Most of the time it's about the Department's demands and needs and not the good of the people ... We are never preoccupied about service delivery, our critical cases, thinking about different solutions to the problem but it's all about this Department ... you can never ever understand in this Department what is really expected of you, because you never complete anything you start due to their disturbances."

\section{SOCIAL WORKERS' RESPONSES TO THE SPLIT BETWEEN RHETORIC AND REALITY}

The typical responses of the social workers were: wanting to opt out of the profession, experiencing a sense of powerlessness and hopelessness, attempting system stabilising efforts, deception, and small pockets of resistance.

Sewpaul and Hölscher (2006:174) state that "in post-apartheid South Africa, examples of purposeful acts of resistance by social workers have been rare, with passive resistance more commonly practised, e.g. leaving their place of work". Seven out of the ten participants said they were seeking employment elsewhere. Some of them wanted to opt out of social work altogether. One social worker resigned during the course of this study despite having no other employment, as she could no longer deal with the work stress.

The dynamics of oppression are such that they frequently contribute to hopelessness and helplessness, combined with the internalisation of oppression, which compromises the goal of liberation (Friere, 1970). Some social workers in this study expressed feelings of hopelessness and felt that they had no power to change their predicament. In the words of one participant: "I don't bother myself with things I know very well that I'll never get". They feared victimisation and losing their source of income through forced resignation, which some claimed they had witnessed in the workplace. One participant said:

"You must just recycle the paper so that you give them the reports they so aggressively and forcefully demand. You do these things in order to make sure that you don't lose this 'temporary employment', because really as much as people speak about being in democracy but we tend to think that democracy does not fully exist ... You rather prefer to keep quiet and tell yourself that I'll 
cope with what is available and persevere until I reach my retirement time because there is nothing you can do... If they ask why haven't you submitted the required reports, you can't say these are the challenges I've had, because they will think you are being rude."

System stabilising efforts included buying and using personal resources, such as stationery and computers, in an attempt to meet the demands, respond to service users' needs, and to protect the department from negative reactions from the public. Six reported that they reverted to buying paper in order to print reports. Four reported that they took their own money to buy snacks for youths who came for training sessions. Some used their own vehicles to conduct awareness campaigns and make home visits in emergency instances.

One participant, laughing with an expression of shame, said: "You know sometimes I steal cars allocated to other colleagues knowing very well that they also need it. But with the pressure to meet targets, I become selfish and deprive other people the opportunity to fulfil their jobs ... I steal not because I want to but because there is a hard push for production and meeting of targets ... When they ask for outputs, you cannot start your sentence with 'I had no car'". The negative effect is that it "causes a lot of conflict between us but I am compelled to do it ... I can't help it."

Sometimes the dissatisfaction was manifested in openly expressed resistance among a few social workers, who confidently and firmly opposed the authoritarianism of the management in meetings. Although the majority of social workers succumbed and used the silent approach, when they had lunch or tea together the silent ones would applaud and encourage the outspoken ones to continue opposing the bureaucracy and authoritarianism in the organisation.

\section{CRITICAL THEORY IN ACTION}

Critical theory postulates that "social structures are oppressive and they are maintained through political and economic power and supported by a range of legitimising structures" (Humphries, 2008:106). The research process demonstrated the power of critical theory in action. Through engagement in reflexive dialogue, social workers began to appreciate that they were not merely passive victims of the system. They began to see themselves as people who could be assertive and challenge some of the conditions that impacted on their functioning. Babbie and Mouton (2001:34) assert that a distinctive feature of critical theory is that science must not only be used "to explain and understand society, but to change it for the better", a view supported by Miller and Brewer (2003:60), who contend that the central feature of critical theory is that "research is a political activity, working either for or against the status quo".

Freire (1970, 1973) and Sewpaul (2014b) state that raising critical consciousness could provide the platform for emancipation and transformative action, which was to a certain extent achieved through this research process. The in-depth interviews and the focus group discussion served as a catalyst for resistance amongst those who were involved in the process. Rather than simply accept instructions, social workers began to show a willingness to ask questions, seek clarification from management, and they made 
decision not to engage in system-stabilising efforts. One of their acts of resistance included drafting a petition, signing and faxing it to the head office and their union. They detailed their dissatisfaction about the working conditions and the treatment from their superiors. Although this caused tension amongst workers and management, it settled after a while, as management did begin to listen to the social workers.

Through their engagement in the research process, the majority of social workers began to develop a sense of solidarity amongst themselves and made decisions to take collective action. There appeared to be more trust between them and the fear of betrayal decreased. In one instance the MEC had promised to provide some service users with food and school uniforms. Social workers profiled those families and found that they were indeed needy. The MEC was supposed to hand over the items to the families, which did not happen. Instead she sent an instruction, which was bound to cause conflict between the social workers and the service users. In a common show of solidarity the social workers refused to follow the instruction of the MEC. They informed management that they were not going to work that day until the promise made to the service users was fulfilled. This was relayed to the MEC, who then gave management the go-ahead to provide the supply. In addition, social workers persistently requested phone codes to be in touch with service users; these were eventually granted, one year after the initial request. Citing Smith, Hendrickson (2012:57) concluded that, "it is often through small, everyday acts of resistance that social workers find opportunities for social justice work in mainstream practice settings". Small, everyday acts hold enormous symbolic value and potential to destabilise systems.

\section{CONCLUSIONS AND RECOMMENDATIONS}

The results of this study confirm that social workers are confronting "the harsh realities of commodity production: speed-up, routinisation of work, greater work discipline and ... the insistent managerial pressures to reduce labor costs" (Noble, 1999:46). What is also evident in the findings is neglect of the development of critical thinking with neoliberal and managerialist discourses on what works, narrowly defined evidence, and doing more with fewer resources (Clarke, 2007; Giroux, 2002; Sewpaul \& Hölscher, 2004, Sewpaul, 2014a). Neoliberalism and managerialism have increased surveillance and control (Noble, 1999), and replaced collegiality and trust with contracts, competitiveness, individuality and performance indicators, supporting a compliant and technically skilled workforce (Roberts, 2009) rather than critically reflexive professionals. Rationalisation of resources and downsizing of staff, rather than investment in people, are becoming naturalised features of social work organisations and of tertiary education institutions (Chomsky, 1999; Lavalette \& Ferguson, 2007; Sewpaul, 2014a; 2015). These are accompanied by incentives for staff who do comply, and with disincentives and/or threats for those who do not, so much so that ethical resistance politics are losing ground both in social work practice and in academia (Sewpaul, 2014a). If academics, who might have more privilege and agency than their practice counterparts, capitulate to the hegemonic discourses of neoliberalism and managerialism or lack awareness of their impacts, it is less likely that graduates would, on beginning practice, challenge pernicious features of the status quo. 
While social work is a calling (or ideally ought to be), it is also a profession and an academic discipline requiring several years of academic study. Social workers deserve decent work conditions, respect, trust and autonomy to facilitate fulfilment of their professional responsibilities. The results of this study indicate that the lack of resources, top-down hierarchical management, political interference, cost containment and the privileging of targets and numbers above people-centred development contribute to conflicts among colleagues, subterfuge, demoralisation, hopelessness and the desire to opt out of the profession.

However, as this research has shown, even in a government-driven organisation, managed by neoliberal and managerialist agendas, social workers are not without agency. While social workers are oppressed, it must be understood that their service users are often far more disadvantaged and oppressed than they are. It is the ethical responsibility of the social worker to challenge structural conditions in the workplace for their own wellbeing and satisfaction. More importantly, they need to reclaim their professional spaces to render the best possible services, and to engage people in the most empowering and liberating ways possible, taking into account inter-related civil and political rights; socio-economic and cultural rights; and environmental rights, including the right to species biodiversity and inter-generational equity (Sewpaul \& Larsen, 2014b). Although these are given attention on an international level (Dominelli, 2012), they have largely eluded South African social work, perhaps on account of the severity and intensity of psychosocial problems confronting South African society, the urgency with which cases have to be dealt with, the high workloads and poor resources, and the lack of attention to this in the social work curricula.

Leonard (1997:166) calls for a practice which "enables subjects to express individual resistance to domination and the possibility of participating in collective resistance in the pursuit of claims for welfare". As there is a nexus between education and practice, this calls for emancipatory education so that graduates can become engaged citizens who challenge oppression and injustices (Sewpaul, 2014c). Emancipatory education can and should serve as the bedrock of preparation for legitimate resistance to injustice. Creating space for resistance and solidarity is also important. The reflexive dialogue that occurred through the in-depth interviews and the focus group prompted social workers to coalesce around some common agendas in this study. However, for such initiatives to be sustained, reflexive dialogue and critical engagement need to occur on a consistent basis within organisations, and across the spectrum of social service agencies, without fear of reprisal. In support of people-to-people solidarity, these initiatives need the backing of bodies such as the National Association of Social Workers, South Africa, the Association of South African Social Work Education Institutions, the National Coalition of Social Services, the South African Council for Social Service Professions, and key trade unions that social workers belong to. 


\section{REFERENCES}

ALPASLAN, N. \& SCHENCK, R. 2012. Challenges related to working conditions experienced by social workers practicing in rural areas. Social Work/Maatskaplike Werk, 48(4):400-419.

ALVESSON, M. \& SKÖLDBERG, K. 2009. Reflexive methodology. New vistas for qualitative research. London: Sage Publications.

BALDAUF, S. 2010. South Africa AIDS orphans overwhelm social work services. [Online] Available: http://www.csmonitor.com/World/Africa/2010/0510/South-AfricaAIDS-orphans-overwhelm-social-work-services [Accessed: 21/08/2015].

BAUMAN, Z. 1993. Postmodern ethics. Oxford: Blackwell Publishing Ltd.

CARPENTER, J. \& WEBB, C. 2012. Effective supervision in social work and social care. Bristol: Social Care Institute for Excellence.

CHOMSKY, N. 1999. Profit over people - neoliberalism and global order. New York: Seven Stories Press.

CLARKE, J. 2007. Subordinating the social? Neoliberalism and the remaking of welfare capitalism. Cultural Studies, 21(6):974-987.

DE VOS, A.S., STRYDOM, H., FOUCHÉ, C.B. \& DELPORT, C.S.L. 2010. Research at grassroots: for the social services and human service professions. Pretoria: Van Schaik Publishers.

DENZIN, K.N. \& LINCOLN, Y.S. 2011. The Sage handbook of qualitative research. New York: Sage Publications.

DEPARTMENT OF HIGHER EDUCATION AND TRAINING (DHET). 2014. White Paper for Post-School Education and Training: Building an Expanded, Effective and Integrated Post-School System. Pretoria: DHET.

DEPARTMENT OF SOCIAL DEVELOPMENT (DSD). 2013. Framework for Social Welfare Services. Pretoria: DSD.

DEPARTMENT OF WELFARE. 1997. White Paper for Social Welfare. Government Gazette Notice 1108 of 1997. Pretoria: Ministry for Welfare and Population Development.

DOMINELLI, L. 1996. Deprofessionalising social work: anti-oppressive practice, competencies and postmodernism. British Journal of Social Work, 26:153-175.

DOMINELLI, L. 2002. Anti-oppressive social work theory and practice. Basingstoke: Palgrave Macmillan.

DOMINELLI, L. 2012. Green social work: from environmental crises to environmental justice. Cambridge: Polity Press.

FERGUSON, I. \& LAVALETTE, M. 2006. Globalization and global justice. International Social Work, 49(3):309-318. 
FREIRE, P. 1970. The pedagogy of the oppressed. Harmondsworth, England: Penguin Books.

FREIRE, P. 1973. Education for critical consciousness. New York: Seabury Press.

FUCHS, C. \& SANDOVAL, M. 2008. Positivism, postmodernism, or critical theory? A case study of communications students' understandings of criticism, Journal for Critical Education Policy Studies, 6(2):112-141.

GIROUX, H.A. 2002. Neoliberalism, corporate culture, and the promise of higher education: the university as a democratic public sphere. Harvard Educational Review, 72(4):425-463.

GRAMSCI, A. 1988. Gramsci's prison letters (Translated by Henderson, H.). Edinburgh: Zwan Publications.

HENDRICKSON, S. 2012. Legitimizing resistance to organizational change: a social work social justice perspective. International Journal of Humanities and Social Science, 2(5):50-59.

HENNING, E. 2004. Finding your way in qualitative research. Pretoria: Van Schaik Publishers.

HÖLSCHER, D. \& SEWPAUL, V. 2006. Ethics as a cite of resistance: the tension between social control and critical reflection. In: HALL, N. (ed). Social work: making a world of difference. Berne: IFSW.

HOWE, D. 1996. Surface and depth in social work practice. In: PARTON, N. (ed). Social theory, social work and social change: the state of welfare. London: Routledge.

HUMPHRIES, B. 2008. Social work research and social justice. Hampshire: Palgrave, Macmillan.

IOAKIMIDIS, V. 2013. Arguing the case for a social justice based global social work definition. Critical and Radical Social Work, 1(2):183-200.

LAVALETTE, M. \& FERGUSON, I. 2007. Towards a social work of resistance: international social work and the radical tradition. In: LAVALETTE, M. \& FERGUSON, I. (eds). International social work and the radical tradition. Birmingham: Venture Press.

LEONARD, P. 1997. Postmodern welfare. Reconstructing an emancipatory project. London: Thousand Oaks.

LINCOLN, Y.S. \& GUBA, E.G. 1985. Naturalistic inquiry. Newbury Park, CA: Sage Publications.

MILLER, R.L. \& BREWER, J.D. 2003. The A-Z of social research. London: Sage Publications.

NEUMAN, W.L. 2006. The meanings of methodology. In: NEUMAN, W.L. (ed). Social research methods: qualitative and quantitative methods. New York: Pearson. 
NOBLE, D. 1999. Digital diploma mills. London: Monthly Review Press.

ROBERTS, P. 2009. A new patriotism: neoliberalism, citizenship and tertiary education in New Zealand. Educational Philosophy and Theory, 41(4):410-423.

RUBIN, A. \& BABBIE, E. 2011. Research methods for social work. Belmont: Brooks/Cole.

SEPTEMBER, R.L. 2007. Separating social welfare services and social welfare grants: challenges and opportunities. Social Work/Maatskaplike Werk, 43(2):93-105.

SEWPAUL, V. \& HÖLSCHER, D. 2004. Social work in times of neoliberalism: a postmodern discourse. Pretoria: Van Schaik Publishers.

SEWPAUL, V. 2013. Neoliberalism and social work in South Africa. Critical and Radical Social Work, 1(1):15-30.

SEWPAUL, V. 2014a. Social work education: current trends and future directions. In: NOBLE, C., STRAUSS, H. \& LITTLECHILD, B. (eds). Global social work: crossing borders, blurring boundaries. Sydney: Sydney University Press.

SEWPAUL, V. \& LARSEN, A.K. 2014b. Community development: towards an integrated emancipatory framework. In: LARSEN, A.K., SEWPAUL, V. \& OLINE, G. (eds). Participation in community work: international perspectives. London: Routledge.

SEWPAUL, V. 2014c. Emancipatory education: towards engaged citizenship, democratic practices and active community engagement. In: DOMINELLI, L. \& MOOSA-MITHA, M. (eds). Reconfiguring citizenship: social exclusion and diversity within inclusive citizenship practices. Hampshire: Ashgate.

SEWPAUL, V. 2015. Neoliberalism. International Encyclopedia of the Social and Behavioral Sciences, 16:462-468.

SHENTON, A.K. 2003. Strategies for ensuring trustworthiness in qualitative research projects. Education for Information, 22:63-75.

TERREBLANCHE, M. \& DURRHEIM, K. 1999. Research in practice: applied methods for the social sciences. Cape Town: University of Cape Town Press.

YOUNG, I. 2004. Five faces of oppression. In: HELDKE, L. \& O'CONNER, P. (eds). Oppression, privilege and resistance. Boston: McGraw Hill.

Ms Thembeni True-love Dlamini, practicing social worker and postgraduate student; Prof Vishanthie Sewpaul, The School of Applied Human Sciences, University of KwaZulu-Natal, Durban, South Africa. 